\section{Still I Rise}

When we are born, they give us a name, a name that becomes our identity and throughout our life we get many such titles that define who we are - a daughter, a wife, and a mother. But, at the age of merely 35 , I received one more title of "cancer survivor." This is the story of my battle, my survival, and also my journey of self-discovery.

It all began with a mild pain in my left breast, right after my breastfeeding period was over. Like any other ignorant woman, I neglected it for some time, assuming it is all related to feeding or hormonal cycle. However, the pain was quite consistent and therefore, I visited my gynecologist for a consultation. She recommended a few medications, but the pain continued to be there. Hence, a mammography was carried out and that changed my entire life. After all I was physically fit, never smoked, and even worked out regularly.

In our society, the word "cancer" is synonymous with death and a taboo that no one wants to talk about. As a first step, I refrained from discussing the situation with relatives, and only selected close members were made aware. This acted as an excellent barrier to filter all the negativity and sad looks from the people. It is highly crucial on my part as a patient to stay positive. The best thing to do is to take one day at a time, stay positive, and remember that this is not the end. Like any motivational quotes, these things are easy to say but very difficult to follow when you are going through such extreme physical pain. However, if you could achieve and maintain that serenity throughout the treatment, nothing can kill you.

My treatment started with neoadjuvant therapy, i.e., chemotherapy was given before the surgery. It included a total of eight sessions; four before and four planned after the surgery with an interval of 15 days. Most people, especially women, suffer from depression that comes after severe hair loss during these sessions. After going through a similar phase in the first two sessions, I shaved my entire head to save myself from any trauma.

"Diary of a young girl pulled me out of my misery!"

My love for books and faith in science helped me endure the rigors of treatment and helped me get through the toughest moments. "I now have a lot of time to read many books" I promised myself. But, right after my first chemo, I had such severe nausea and vomiting. I was unable to sit and read for long periods of time. I had to struggle to keep myself positive and hopeful. My dad would sit next to me and read me stories, stories of Anne Frank, my favorite book since childhood, a story that reminds us of the importance of hope, faith, and love in the face of adversity. Even though the story is related to anxiety, cruelty, and fear of death, I could relate to the struggle for survival.

\section{"Coping with unexpected twist"}

I was hopeful that with such a strong chemo dosage, the cancer will shrink and surgery will not be required. However, I was asked to take a BReast CAncer gene test to determine if I have a mutation in the DNA and an increased risk of cancer to the ovaries as well. I had no family history and as per my doctor, I was too young to develop the cancer. The test results were positive which means that my right healthy breast was equally susceptible to cancer and so were my ovaries. It was a big realization as my future changed suddenly, and I was left with only the choice of whether to be afraid of it or take firm, confident steps hoping that everything will be alright one day.

Hence, I took the decision to go under preventive surgery as well including complete removal of both breasts. This decision of bilateral mastectomy was a big moment in my life; one that divided my life into "before" and "after" parts. Being a woman, it was tough, and I started feeling depressed as if the surgery will make me any less of a woman. My doctors and my husband played a major role in listening to my constant queries, consoling me that it is not the end of the world and my life is much more valuable than this little bump on the road.

My doctor carried out the mastectomy and 18 lymph nodes from my left armpit were removed. After adequate rest, the remaining chemo-sessions were also completed, followed by 30 days of radiation therapy.

Will I able to have a child one day?

This is the question that I had in mind since the beginning of the treatment. I have a daughter. My husband and I both wanted to have another child someday. Because initially the disease was only related to the breast, I was consoling myself that one day when I am back in my healthy state, I might be able to have another child. However, after my test for estrogen receptors and progesterone receptors and BRCA test, my doctor explained how it is not possible. He comforted me that it is rather important to focus on my health and making sure that my daughter has a mom. It was a devastating moment for me; it was the only time when I cried. My family encouraged me to be with my truth, giving myself the space to cry without judgment. In that crucial time, no one forced me to feel positive and this helped me cope with the worst news and move on.

The treatment continued for 7-8 months, and it took me a year and a half, to get where I felt like myself again. Just the way at the end of a storm, we learn how strong we were to survive it. I felt blessed to be alive and spent all my time with my loved ones, especially my daughter. 
If there is one thing that I learned from this, it is that when you can't run, don't surrender. Rather stand your ground and give it a good fight. How we manage our suffering is up to us, we meditate, we pray, we embrace it, and the best way is to push through it.

\section{Financial support and sponsorship}

Nil.

\section{Conflicts of interest}

There are no conflicts of interest.

\section{Prachi Kulkarni \\ Address for correspondence: Prachi Kulkarni,}

303. Maxima A, CasaBella Gold, Lodha Palava City, Dombivali East - 421204, Maharashtra, India. E-mail: prachi.tarawade@gmail.com
Submitted: 12-May-2020

Revised: 29-Jun-2020

Accepted: 04-Aug-2020

Published: 29-Oct-2020

This is an open access journal, and articles are distributed under the terms of the Creative Commons Attribution-NonCommercial-ShareAlike 4.0 License, which allows others to remix, tweak, and build upon the work non-commercially, as long as appropriate credit is given and the new creations are licensed under the identical terms.

\begin{tabular}{|l|l|}
\hline \multicolumn{2}{|c|}{ Access this article online } \\
\hline Quick Response Code: & Website: \\
& www.ijmpo.org \\
\cline { 2 - 2 } & DOI: \\
\hline
\end{tabular}

How to cite this article: Kulkarni P. Still I rise. Indian J Med Paediatr Oncol 2020;41:727-8. 